\title{
El secretito del coco
}

\section{Henry A. Petrie ${ }^{1}$}

A la memoria de mi hija Tania Tamara, que tuvo fascinación por Bluefields y deseó

conocer el encanto de Laguna de Perlas.

B luefields estaba prendida. El ritmo dictaba el zangoloteo de cuerpos y las comparsas lucían colores vivaces. De los poros emergían sudores que bañaban pieles. Mayo Ya, sonaba bajo sol brisado en espléndido Caribe. Humedad, movimiento, tambores, piernas en ejecuciones elásticas y el palo con cintas para clímax con rondón, raice and bean, cervezas, patí picante, chacalines en salsa, camarones en ceviche, Quiero fruta de pan, pijibay, icaco en miel ¿Dónde encuentro tortillas de harina?, y mayo sigue en movimiento, las cintas van cubriendo el palo.

Pero William Tuckler no estaba contento. Buscaba angustiado el coco que había escondido en un rincón de su casa para abrirlo y beberse el agua justo ese día, tal como el viejo Robert Omier se lo indicó: "Guardá el coco, boy, y déjalo tranquilo hasta después de mi muerte. A las fiestas de mayo que sigan, en el día más importante ábrelo y bebe su agua, que yo te mostraré el secretito, boy, para que seas feliz como criatura del paraíso, my son". El muchacho, entonces, tuvo que esperar tres meses más para cumplir al pie de la letra las palabras de don Robert. Pero el coco ya no estaba. El coco, el coco... había desaparecido y de tanto buscar y preguntar, remover y desordenar, la madre se enojó y lo mandó a cortar cuanto quisiera a los cocales. Pero no, el coco tenía que ser el mismísimo que le dio el finado Omier. Era ese el coco, el coco perdido... el secretito... tenía que encontrarlo, abrirlo y beberse el agua.

William Tuckler quería el coco que don Robert le dio. Alguien se lo había robado o por equivocación lo botó. Pero ¿quién?, si nadie sabía del coco, nadie, el coco estaba bien guardado, y de tanto buscar, el Mayo Ya, se iba con todo, menos con coco. William enloquecía, lloraba, invocaba al finado que sólo se fue después de ingerir tres tragos dobles de ron y escuchar su música. Se quedó quietecito, como si estuviera bolo. El espíritu se le fue muy contento al viejo negro de Laguna de Perlas.

A lo largo de la avenida con aceras colmadas de gentes, la juventud danzaba, movimiento de nalgas y pelvis, chorros de sudores, el palo, palo de mayo, mayo ya, cintas de colores, y el ritmo, ¡cómo brota de los poros!, transpiración corporal, sexual, y la ciudad vibra, y come, bebe, y arde, tambores truenan y continúan los pasos, Empatamos la serie, tanacatana with fucking Boer, Está bien, sólo por hoy que es bacanal no me digás «español» porque no lo soy. ¡Ah!, y dejate de racismos que aquí debemos ser un solo corazón caribeño. El Palo de Mayo, está agua-ardiendo en esquinas y serenito anda mister Alcalde con chelotas turistas, jya ves!, ahí no hay color que valga.

Pero William estaba casi muerto porque no aparecía el coco. El Mayo Ya, estaba acabando sin descubrimiento del secreto. Nada de coco, nada de agua. ¿Dónde está, quién lo robó? Frustrado recordó al viejo Omier y lloró de impotencia. Caminó sin propósito y frente a la bahía reclamó al crepúsculo su infortunio; dejó pasar las horas hasta cuando un fuerte viento helado lo estremeció.

Esa noche estaba tupida de estrellas y la luna presenciaba la fiesta en VIP o actuaba como celestina. Emprendió el regreso a casa entristecido, mientras el apogeo tomaba un nuevo respiro. Baile, comilona y bebedera. En rincones oscuros se escuchaban quejidos placenteros y en el ambiente un olor a marisco insistía.

\footnotetext{
1 Presidente de Acción Creadora Intercultural (ACIC). E-mail: malaji_2004@yahoo.com
}

Recibido: 19/04/2017 Aprobado: 23/o8/2017 
William se sentía descalabrado por la pérdida, cómo pudo permitir semejante extravío del coco regalado por un gran amigo; pero, sobre todo, cómo sabría ahora el secretito que encerraba la fruta. Retornaba concentrado en recriminaciones, hasta cuando frente a su casa, observó que una hermosa joven negra estaba cómodamente sentada en el corredor con barandas multicolor. Lo esperaba desde hacía una hora y se presentó como hija de Robert Omier. Alta, fornida, labios carnosos, tetas redondas, sonrisa tímida y mirada sensual. Vaya, pensó, el viejo Omier se lo tenía guardadito. Salió con una hija. Laguna de Perlas, ¡claro!, donde una sirena negra nada desnuda a sus anchas, como manatí, integrada al nocturno de luna encendida, se lo contaba cuantas veces lo visitó. La fruta que había buscado casi demencial estaba en sus manos. ¡El coco! Y le preguntó cómo había llegado a ella.

Mi nombre es Sirena Omier, hija de tu amigo Robert. Vengo a llevarte conmigo, allá... Laguna de Perlas. My dari dijo que me casara cuando él, convertido en destello, me llevara un coco, de mañanita, junto a la cama. Así lo hizo. Entonces hablé con él y me dijo que te buscara, porque estarías muy triste y que serás mi hombre para hacerte feliz. Por eso estoy aquí, salí de Laguna de Perlas y vine por vos, hay una concha que espera en la bahía ¿Vienes?

William Tuckler no titubeó y se fue sin avisar. Su familia lo buscó, pero no hubo rastros, nadie supo nada del raro creole. Mas, Mayo Ya, se celebró en la ciudad caribeña, pero qué mejor fascinación la del joven que los nocturnos de lunas encendidas, los vuelos solares de garzas y los fluidos de agua de coco que en cada beso recibía de Sirena.

Diciembre 2009. (Este cuento integra la colección Fiestero, inédita, de Henry A. Petrie). 